\title{
Studies on the production of glucose isomerase by Bacillus licheniformis
}

\author{
Ogbonnaya Nwokoro \\ University of Nigeria, Industrial Microbiology and Biotechnology Laboratory, Department of Microbiology, Nsukka, \\ Nigeria, e-mail: ogbonnaya.nwokoro@unn.edu.ng
}

\begin{abstract}
This work reports the effects of some culture conditions on the production of glucose isomerase by Bacillus licheniformis. The bacterium was selected based on the release of $3.62 \mathrm{mg} / \mathrm{mL}$ fructose from the fermentation of glucose. Enzyme was produced using a variety of carbon substrates but the highest enzyme activity was detected in a medium containing $0.5 \%$ xylose and $1 \%$ glycerol (specific activity $=6.88 \mathrm{U} / \mathrm{mg}$ protein). Media containing only xylose or glucose gave lower enzyme productivies (specific activities $=4.60$ and $2.35 \mathrm{U} / \mathrm{mg}$ protein respectively). The effects of nitrogen substrates on glucose isomerase production showed that yeast extract supported maximum enzyme activity (specific activity $=5.24 \mathrm{U} / \mathrm{mg}$ protein). Lowest enzyme activity was observed with sodium trioxonitrate (specific activity $=2.44 \mathrm{U} / \mathrm{mg}$ protein). In general, organic nitrogen substrates supported higher enzyme productivity than inorganic nitrogen substrates. Best enzyme activity was observed in the presence of $\mathrm{Mg}^{2+}$ (specific activity $=6.85 \mathrm{U} / \mathrm{mg}$ protein) while $\mathrm{Hg}^{2+}$ was inhibitory (specific activity $=1.02 \mathrm{U} / \mathrm{mg}$ protein). The optimum $\mathrm{pH}$ for best enzyme activity was 6.0 while optimum temperature for enzyme production was $50^{\circ} \mathrm{C}$.
\end{abstract}

Keywords: glucose isomerase, carbon sources, nitrogen sources, metal ions.

\section{INTRODUCTION}

Glucose isomerase (GI) (E C 5.3.1.5) is one of the three tonnage value enzymes, amylase and protease being the other two 1 . GI catalyzes the reversible isomerization of D- glucose and D- xylose to D-fructose and D- xylulose, respectively. Interconversion of xylose to xylulose serves a nutritional requirement in saprophytic bacteria that thrive on decaying plant material and also aids in the bioconversion of hemicellulose to ethanol ${ }^{2}$. Isomerization of glucose to fructose is of commercial importance in the production of high fructose corn syrup (HFCS). Silva et $a l^{3}{ }^{3}$,noted that the largest application of the technology of immobilized enzymes over the last 40 years has used GI.

GI is an intracellular enzyme produced from a range of genera principally Streptomyces, Bacillus, Corynebacterium and Arthobacter spp. and the organisms are grown on media containing glucose and/or xylose as the free sugar ${ }^{4}$. GI has also been produced from Escherichia coli ${ }^{5,6}$ and from Pichia pastoris ${ }^{7}$. High fructose syrup produced by the activity of glucose isomerase is a useful sweetener; principally in carbonated beverages. According to Lawal et al. ${ }^{4}$,fructose has found a wide market in the United States in her soft drink industries.

Fructose is the sweetest of various naturally occurring sugars and there has been a large demand for it as an alterative to sucrose ${ }^{8}$. Glucose isomerase is used to produce high fructose corn starch. This process involves several separate enzymatic steps including liquefaction of corn starch by amylase, scarification by glycosidase and isomerization by glucose isomerase ${ }^{9}$. Fructose has long been recognized as a good alternative source of sugar due to its relatively high sweetness and other desirable physical and chemical properties. It has been reported to be 1.7 times sweeter than sucrose and it is widely used in food processing and formulation in pharmaceuticals ${ }^{\mathbf{1 0}}$. Increasing demands for refined sugar, compiled with its rising price and the adverse effects of saccharine consumption on human health have necessitated the search for acceptable sucrose alternatives ${ }^{11}$. Interests in converting glucose to fructose have attracted the atten- tion of researchers who concerted their efforts towards maximizing fructose yield and minimizing the cost of all associated processes ${ }^{12}$. This present work studies the effects of some culture conditions on the production of glucose isomerase by Bacillus licheniformis.

\section{MATERIAL AND METHODS}

Soil samples (ca. $20 \mathrm{~g}$ ) was collected near a local corn mill into sterile polyethylene bags. A $10 \mathrm{~g}$ sample was dissolved in $90 \mathrm{~mL}$ of distilled water $(\mathrm{pH}=6.5)$ contained in $500 \mathrm{ml}$ Erlenmeyer flask and thoroughly shaken. Then, $1 \mathrm{~mL}$ of the sample was serially diluted in $9 \mathrm{~mL} 0.1 \%$ peptone water diluent. The diluted sample was plated onto Nutrient agar (Oxoid Ltd., UK) and the plates incubated at $35^{\circ} \mathrm{C}$ for $24 \mathrm{~h}$. Pure bacterial cultures were obtained by streaking on fresh agar plates and were assigned arbitrary numbers. A loopfull of each culture was added into $100 \mathrm{~mL}$ medium containing glucose, $2 \%$; yeast extract, $0.05 \% ; \mathrm{KH}_{2} \mathrm{PO}_{4}, 0.05 \%$; $\mathrm{K}_{2} \mathrm{HPO} 0_{4}, 0.01 \%$ and $\mathrm{MgSO}_{4} \cdot 7 \mathrm{H}_{2} \mathrm{O}, 0.05 \%$ and incubated with shaking in a Gallenkamp orbital incubator for $24 \mathrm{~h}$ at $35^{\circ} \mathrm{C}$. The medium was centrifuged at $2515 \mathrm{x}$ g for 10 minutes in a Gallenkamp Junior centrifuge and the supernatant was assayed for fructose content. The isolate with the code number, A09 was selected for further work because it produced a maximum of $3.62 \mathrm{mg} / \mathrm{mL}$ fructose and was later identified as Bacillus licheniformis based on its morphological, physiological and biochemical characteristics as described in Bergey's Manual of Determinative Bacteriology ${ }^{13}$.

\section{Enzyme production and extraction}

Bacterial cells were grown in $100 \mathrm{~mL}$ of medium described above and harvested by centrifugation at $2515 \mathrm{x}$ $\mathrm{g}$ for 15 minutes and washed twice with $0.2 \mathrm{M}$ phosphate buffer ( $\mathrm{pH}$ 6.5). The washed cell suspension was disrupted by sonication for $10 \mathrm{~min}$. using a Biologics Ultrasonic homogenizer Model 150VT (115V/60Hz). Following disruption, the mixture was centrifuged at $2515 \mathrm{x}$ g for 15 minutes. The supernatant fluid was used to measure enzyme activity. 


\section{Enzyme assay}

Enzyme solution $(1 \mathrm{ml})$ in test tubes were incubated with $2 \mathrm{ml}$ of phosphate buffer ( $\mathrm{pH}$ 6.5) containing $1 \%$ glucose at $30 \pm 2^{\circ} \mathrm{C}$ for 60 minutes followed by keeping the tubes in iced bath for $30 \mathrm{~min}$. The amount of fructose formed was determined by the method of Kulka ${ }^{14}$. Briefly $0.5 \mathrm{~mL}$ of the reaction mixture in a test tube was added to $1.5 \mathrm{~mL}$ distilled water. Then $6 \mathrm{~mL}$ of ketose reagent [1:1 ratio of $\mathrm{A}(0.05 \mathrm{~g}$ resorcinol in $100 \mathrm{~mL}$ ethanol] and $\mathrm{B}\left[0.216 \mathrm{~g} \mathrm{FeNH}_{4}\left(\mathrm{SO}_{4}\right)_{2} \cdot 12 \mathrm{H}_{2} \mathrm{O}\right.$ in 1000 $\mathrm{ml} \mathrm{HCl}$ solution] was added. The content of the tube was mixed and immersed in a water bath (Kotterman, Bremen, Germany) at $80^{\circ} \mathrm{C}$ for $40 \mathrm{~min}$. The tube was cooled in ice water and the absorbance measured in a Spectrumlab 23 A spectrophotometer at $480 \mathrm{~nm}$. The absorbance was used to prepare a calibration curve with D- fructose $(0-200 \mu \mathrm{g} / \mathrm{mL})$. One unit of activity was defined as the amount of enzyme that released $1 \mu \mathrm{g}$ of fructose per min. under the assay conditions.

\section{Effect of carbon substrates on enzyme production}

The basal medium for bacterial growth contained different carbon sources as indicated plus $0.5 \%$ yeast extract, $0.5 \%$ peptone in $0.2 \mathrm{M}$ phosphate buffer $(\mathrm{pH}$ 6.5). The culture medium was inoculated with $2.5 \mathrm{x}$ $10^{6}$ colony forming units of Bacillus licheniformis and incubated for $24 \mathrm{~h}$ in a Gallenkamp orbital incubator at $35^{\circ} \mathrm{C}$ followed by enzyme extraction.

\section{Effect of nitrogen substrates on enzyme production}

Culture media contained different nitrogen sources as indicated plus $1 \%$ glucose in $0.2 \mathrm{M}$ phosphate buffer ( $\mathrm{pH}$ 6.5). The culture media were inoculated with 2.5 x $10^{6}$ colony forming units of Bacillus licheniformis and incubated for $24 \mathrm{~h}$ in a Gallenkamp orbital incubator at $35^{\circ} \mathrm{C}$ followed by enzyme extraction.

\section{Partial purification of the enzyme}

The culture supernatant obtained after enzyme production and extraction was pooled and dialyzed overnight against $0.2 \mathrm{M}$ phosphate buffer ( $\mathrm{pH}$ 6.5). Ammonium sulphate was added to the crude enzyme extract to $45 \%$ saturation, incubated for 8 hours with gentle mixing. The solution was centrifuged at $2515 \mathrm{x}$ g for $15 \mathrm{~min}$. and the supernatant was subjected to further stepwise precipitation with ammonium sulphate to 65 and $75 \%$ saturation followed by centrifugation.

\section{Effect of metal ions on enzyme production}

The culture media contained different metal ions plus $1 \%$ glucose, $0.5 \%$ yeast extract, $0.5 \%$ peptone in 0.2 $\mathrm{M}$ phosphate buffer ( $\mathrm{pH}$ 6.5). The culture media were inoculated with $2.5 \times 10^{6}$ colony forming units of Bacillus licheniformis and incubated for $24 \mathrm{~h}$ in a Gallenkamp orbital incubator at $35^{\circ} \mathrm{C}$ followed by enzyme extraction.

\section{The influence of $\mathrm{pH}$ on enzyme activity}

The effect of $\mathrm{pH}$ on activity of partially purified enzyme was determined by using buffer solutions of different $\mathrm{pH}$ (Phthalate- $\mathrm{NaOH}$ buffer $\mathrm{pH} 4.0-5.5$, and Tris-Maleate buffer 6.0 to 8.5 ) for enzyme assay. The buffers were used at a concentration of $0.1 \mathrm{Mol} / \mathrm{L}$. The $\mathrm{pH}$ activity profile of the enzyme was determined by incubating 0.5
$\mathrm{mL}$ of the enzyme contained in test tubes with $0.5 \mathrm{~mL}$ of $1 \%(\mathrm{w} / \mathrm{v})$ glucose prepared in buffers of different $\mathrm{pH}$ values (4.0-8.5) at $40^{\circ} \mathrm{C}$ for $2 \mathrm{~h}$. The reaction was stopped by placing the tubes in iced water and the enzyme activities were determined.

\section{The influence of temperature on enzyme activity}

The influence of temperature on partially purified enzyme activity was studied by incubating $0.5 \mathrm{~mL}$ of the enzyme solution contained in test tube and $0.5 \mathrm{~mL}$ of $1 \%$ glucose solution prepared in $0.2 \mathrm{M}$ phosphate buffer $(\mathrm{pH} 6.5)$ for $3 \mathrm{~h}$ at various temperatures $(25,30,35$, $40,45,50,55,60,65$ and $70^{\circ} \mathrm{C}$ ) in a thermostatic water bath (Kottermann, Bremen, Germany). The reaction was stopped by placing the tubes in iced water and the enzyme activities were determined.

\section{Assay procedures}

Protein content was estimated by the method of Lowry et al. ${ }^{15}$,using bovine serum albumin (Sigma-Aldrich) as a standard. Fructose concentration was determined by the method of Kulka ${ }^{11}$ using 50-200 $\mu \mathrm{g}$ fructose as standard.

\section{RESULTS AND DISCUSSION}

In a screening programme for the selection of the best glucose isomerase producer, twenty isolates were tested and released between 0.11 and $3.62 \mathrm{mg} / \mathrm{mL}$ fructose. A strain of bacteria designated A09 was chosen as a potent GI producer as determined quantitatively based on the release of $3.62 \mathrm{mg} / \mathrm{mL}$ of fructose from glucose contained in the assay medium (Table 1). From the morphological, biochemical and physiological characteristics, the isolate was identified as Bacillus licheniformis.

Although all the carbon substrates supported enzyme production by the bacterium, the best carbon substrate was a combination of $0.5 \%$ xylose and $1 \%$ glycerol (enzyme activity $=6.88 \mathrm{U} / \mathrm{mg}$ protein). Medium containing $0.5 \%$ xylose caused the production of only 4.6 $\mathrm{U} / \mathrm{mg}$ protein while bacterial cultivation in the medium containing $0.5 \%$ glucose produced only $2.35 \mathrm{U} / \mathrm{mg}$ protein. In general, media containing xylose either alone or with glycerol caused higher enzyme activity than media containing only glucose or with glycerol (Table 2). GI

Table 1. Quantitative release of fructose by the isolates

\begin{tabular}{|l|c|}
\hline Isolate & Fructose $[\mathrm{mg} / \mathrm{mL}]$ \\
\hline $\mathrm{AO1}$ & 0.42 \\
\hline $\mathrm{AO} 2$ & 0.13 \\
\hline $\mathrm{AO3}$ & 0.23 \\
\hline $\mathrm{AO} 4$ & 1.63 \\
\hline $\mathrm{AO5}$ & 2.22 \\
\hline $\mathrm{AO6}$ & 0.18 \\
\hline $\mathrm{AO} 7$ & 0.93 \\
\hline $\mathrm{AO8}$ & 1.62 \\
\hline $\mathrm{AO9}$ & 3.62 \\
\hline $\mathrm{AO10}$ & 0.11 \\
\hline $\mathrm{AO11}$ & 2.16 \\
\hline $\mathrm{AO12}$ & 1.14 \\
\hline $\mathrm{AO13}$ & 2.10 \\
\hline $\mathrm{AO} 14$ & 2.30 \\
\hline $\mathrm{AO} 15$ & 0.16 \\
\hline $\mathrm{AO} 16$ & 3.14 \\
\hline $\mathrm{AO} 17$ & 0.56 \\
\hline $\mathrm{AO} 18$ & 2.11 \\
\hline $\mathrm{AO} 19$ & 3.08 \\
\hline $\mathrm{AO} 20$ & 1.55 \\
\hline
\end{tabular}


production from this work was compared to the data on GI production reported by other authors. Deshmukh et al. ${ }^{16}$,obtained the highest yield of $0.40 \mathrm{U} / \mathrm{mg}$ protein when xylose and sorbitol were used as carbon sources for enzyme production at a final $\mathrm{pH}$ of 8.0. Chou et al. ${ }^{17}$, reported the best yield of $1.45 \mathrm{U} / \mathrm{mg}$ protein when the mycelia of Streptomyces species grown in $1 \%$ xylose were subjected to heat treatment in the presence of 0.5 $\mathrm{mM} \mathrm{Co}{ }^{2+}$

GI is an inducible enzyme and xylose is the most potent inducer of the enzyme ${ }^{18}$. The presence of $\mathrm{D}$ -xylose significantly increased the enzyme productivity by Streptomyces spp. ${ }^{19}$. Replacement of D- xylose with glucose reduced GI production. Kwakman and Postma ${ }^{20}$ reported that the presence of glucose in microbial growth media caused reduction in the specific activities of the enzymes involved in the catabolism of other carbon sources. This could be attributed to the repressor effect of glucose on GI synthesis.

Table 3 shows the effect of nitrogen sources on enzyme activity by the bacterium. The best promoter of enzyme activity by the bacterium was generally organic nitrogen sources when compared to inorganic nitrogen sources. Inorganic nitrogen sources caused lower enzyme activity. Yeast extract caused the production of best enzyme yield (5.24 U/mg protein) by the bacterium. Replacement of yeast extract with other nitrogen sources gave lower enzyme yields and the lowest yield was observed in the medium containing $\mathrm{NaNO}_{3}$ as the sole nitrogen source (2.44 $\mathrm{U} / \mathrm{mg}$ protein). The effects of nitrogen substrates on GI production by microorganisms have been reported ${ }^{21}$. Peptone, tryptone and yeast extract supported maximum growth and enzyme production by Streptomyces thermonitrificans and organic nitrogen sources were observed to support the highest GI production when compared to inorganic nitrogen sources ${ }^{16}$. Yassien and Jiman-Fa$\operatorname{tani}^{21}$ reported that a combination of corn steep liquor $(2 \%)$ and yeast extract $(1 \%)$ resulted in an increase in GI production by about 3 to 4 times higher than other nitrogen sources tested.

As shown in Table 4, the tested ions promoted enzyme activity in varying degrees. The best enzyme activity was observed in medium containing $\mathrm{Mg}^{2+}$ followed by $\mathrm{Mn}^{2+}$ which gave enzyme specific activities of 6.85 and 5.20 $\mathrm{U} / \mathrm{mg}$ protein respectively. The lowest enzyme productivity was observed in the medium containing $\mathrm{Hg}^{2+}$ with enzyme productivity at $1.02 \mathrm{U} / \mathrm{mg}$ protein. Glucose isomerase typically requires the presence of divalent metal cautions such as $\mathrm{Mg}^{2+}$ or $\mathrm{Co}^{2+}$ as essential cofactors for their catalytic activity ${ }^{22}$. Kasumi et al. ${ }^{23}$,found that $\mathrm{Co}^{2+}$ gave only $56 \%$ reaction activity as compared to $\mathrm{Mg}^{2+}$, but Ryu et al. ${ }^{24}$, reported that the addition of $\mathrm{Co}^{2+}$

Table 2. Effects of carbon substrates on glucose isomerase activity of Bacillus licheniformis

\begin{tabular}{|l|c|}
\hline C-source & Specific activity [U/mg protein] \\
\hline Xylose $(0.5 \%)$ & $4.60 \pm 0.848$ \\
\hline Glucose $(0.5 \%)$ & $2.35 \pm 0.778$ \\
\hline $0.5 \%$ xylose $+1 \%$ glucose & $3.51 \pm 1.824$ \\
\hline $1 \%$ xylose $+0.5 \%$ glucose & $2.12 \pm 0.735$ \\
\hline $0.5 \%$ xylose $+0.5 \%$ glucose & $3.80 \pm 0.424$ \\
\hline $0.5 \%$ xylose $+1 \%$ glycerol & $6.88 \pm 1.358$ \\
\hline $1 \%$ xylose $+0.5 \%$ glycerol & $5.22 \pm 0.877$ \\
\hline $0.5 \%$ xylose $+0.5 \%$ glycerol & $5.46 \pm 0.622$ \\
\hline $0.5 \%$ glucose $+1 \%$ glycerol & $3.13 \pm 1.485$ \\
\hline $1 \%$ glucose $+0.5 \%$ glycerol & $2.61 \pm 0.566$ \\
\hline $0.5 \%$ glucose $+0.5 \%$ glycerol & $2.80 \pm 0.410$ \\
\hline
\end{tabular}

Mean \pm SD of duplicate experiments

Table 3. Effects of nitrogen substrates on glucose isomerase activity of Bacillus licheniformis

\begin{tabular}{|l|c|}
\hline $\mathrm{N}$-source & Specific activity [U/mg protein] \\
\hline Peptone & $4.86 \pm 0.184$ \\
\hline Yeast extract & $5.24 \pm 0.311$ \\
\hline Tryptone & $3.62 \pm 0.806$ \\
\hline Malt extract & $3.21 \pm 0.325$ \\
\hline Corn steep liquor & $3.64 \pm 0.792$ \\
\hline Urea & $2.81 \pm 0.509$ \\
\hline $\mathrm{NaNO}_{3}$ & $2.44 \pm 0.537$ \\
\hline $\mathrm{KNO}_{3}$ & $2.64 \pm 0.778$ \\
\hline$\left(\mathrm{NH}_{4}\right)_{2} \mathrm{Cl}$ & $3.29 \pm 0.169$ \\
\hline$\left(\mathrm{NH}_{4}\right)_{2} \mathrm{SO}_{4}$ & $3.56 \pm 0.071$ \\
\hline
\end{tabular}

Mean \pm SD of duplicate experiments

Table 4. Effects of metal ions on glucose isomerase activity of Bacillus licheniformis

\begin{tabular}{|l|c|}
\hline Metal ion [0.5 mM] & Specific activity [U/mg protein] \\
\hline Control (No metal ion) & $2.04 \pm 0.099$ \\
\hline $\mathrm{BaCl}_{2}$ & $3.11 \pm 0.024$ \\
\hline $\mathrm{CaCl}_{2}$ & $2.56 \pm 0.707$ \\
\hline $\mathrm{MnCl}_{2}$ & $5.20 \pm 0.552$ \\
\hline $\mathrm{ZnCl}_{2}$ & $2.93 \pm 0.325$ \\
\hline $\mathrm{CuCl}_{2}$ & $3.64 \pm 0.028$ \\
\hline $\mathrm{CoCl}_{2}$ & $4.68 \pm 0.466$ \\
\hline $\mathrm{HgCl}_{2}$ & $1.02 \pm 0.057$ \\
\hline $\mathrm{MgSO}_{4} \cdot 7 \mathrm{H}_{2} \mathrm{O}$ & $6.85 \pm 0.382$ \\
\hline $\mathrm{AgNO}_{3}$ & $2.39 \pm 0.877$ \\
\hline
\end{tabular}


into a culture medium stimulated the formation of GI. Treatment of purified enzyme with EDTA resulted in an almost complete loss of enzyme activity but the activity was restored by the addition of metal ions ${ }^{25}$.

The effect of different buffers and $\mathrm{pH}$ on enzyme activity is shown in Figure 1. The enzyme was active over the whole range from $\mathrm{pH} 4.0-8.5$ with maximal activity at $\mathrm{pH} 6.0$ at which the enzyme retained $100 \%$ of its activity Lowest activity was observed at $\mathrm{pH} 8.5$ at which the enzyme lost $62 \%$ of its activity. Ryu et al. ${ }^{24}$, showed $\mathrm{pH} 8.3$ to be optimal for glucose isomerase production while Danno ${ }^{\mathbf{2 6}}$, Chen et al. ${ }^{\mathbf{1 8}}$, and Yassien and Jiman-Fatani ${ }^{21}$ reported $\mathrm{pH}$ optima at 7.0 with the following microorganisms: Bacillus coagulans, Streptomyces flavogriseus and Streptomyces albaduncus respectively. Lawal at $\mathrm{al}^{4}$ reported $\mathrm{pH}$ optimum at 10.0 with Bacillus spp. The optimum $\mathrm{pH}$ for GI production was in the range between $\mathrm{pH}$ 7.0-9.0 . The optimum $\mathrm{pH}$ for GI production was slightly acidic, pH 6.9 for Streptomyces species ${ }^{8}$.

The effect of temperature on enzyme activity showed $50^{\circ} \mathrm{C}$ as optimum temperature. The enzyme showed $100 \%$ activity at $50^{\circ} \mathrm{C}$ and lowest activity at $25^{\circ} \mathrm{C}$ at which $58 \%$ of its activity was lost. This is in line with the report of Gaily et al. ${ }^{\mathbf{1 2}}$, that during enzymatic isomerization of glucose, temperature is preferably maintained within the range of $20-90^{\circ} \mathrm{C}$ and the highest activity was obtained within $50-75^{\circ} \mathrm{C}$. Optimal enzyme activity of glucose isomerase was observed at $42-43^{\circ} \mathrm{C}$ by Ryu et al. ${ }^{24}$, while Yassien and Jiman-Fatani ${ }^{\mathbf{2 1}}$ reported a suitable temperature for microbial growth and GI production in the range of $25-35^{\circ} \mathrm{C}$ for Streptomyces albaduncus.

\section{CONCLUSION}

The stimulatory effects of glycerol on glucose isomerase activity by Bacillus licheniformis was observed in media containing different carbon sources. Yeast extract was found to be the most suitable nitrogen source for enzyme production. Among the metal ions tested for enzyme activity, magnesium sulphate gave the best enzyme activity of $6.85 \mathrm{U} / \mathrm{mg}$ protein while the lowest enzyme activity of $1.02 \mathrm{U} / \mathrm{mg}$ protein was produced with mercury chloride. The enzyme activity produced at $\mathrm{pH} 6.0$ was higher than at other $\mathrm{pH}$ levels. The optimum temperature for enzyme activity was found to be at $50^{\circ} \mathrm{C}$. It would be possible to produce commercial amounts of this enzyme using the test bacterium, however, further kinetic studies on enzyme production need to be studied.

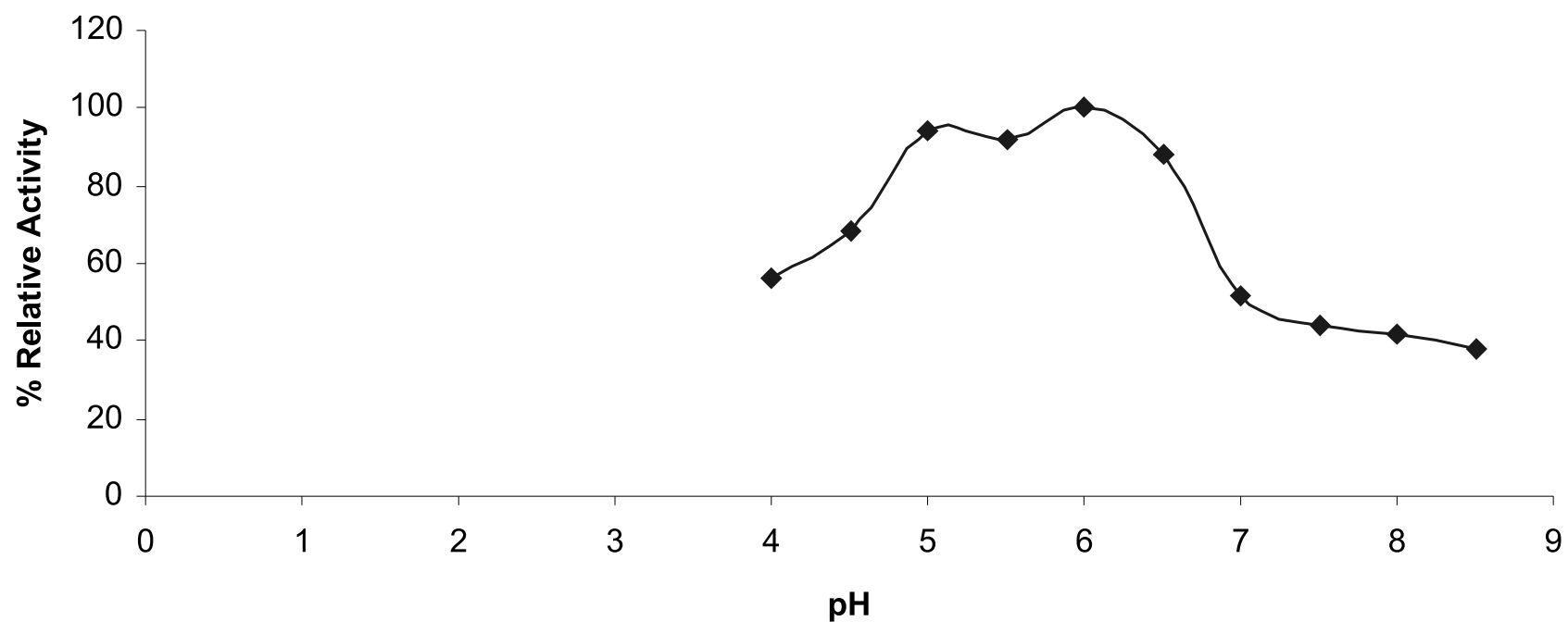

Figure 1. Effects of initial $\mathrm{pH}$ on glucose isomerase activity of Bacillus licheniformis

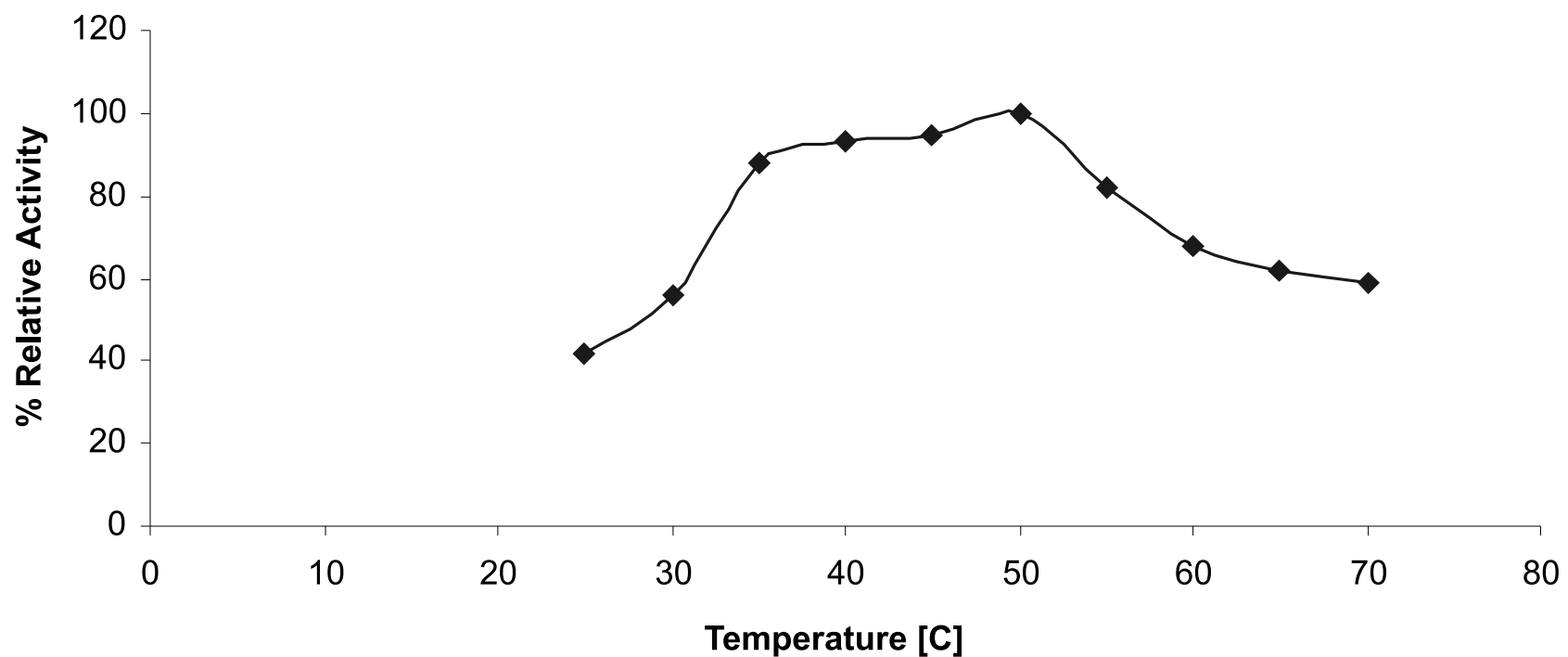

Figure 2. Effects of temperature on glucose isomerase activity of Bacillus licheniformis 


\section{LITERATURE CITED}

1. Bhosale, S.H., Rao, M.B. \& Deshpande, V.V. (1996). Molecular and industrial aspects of glucose isomerase. Microbiol. Rev. 60, 280-300. PMID 8801434.

2. Priya, C. \& Virendra, S.B. (2000). Application of a compatible xylose isomerase in simultaneous bioconversion of glucose and xylose to ethanol. Biotechnol. Bioproc. Engineering 5, 32-39. DOI: 10.1007/BFO2932350.

3. Silva, E.A.B, Souza, A.A.U., Rodrigues, A.E. \& Guelli, S.M.A. (2006). Glucose isomerisation in simulated moving bed reactor by glucose isomerase. Braz. Arch Biol Technol. 49: 491-502. http:dx.doi.org/10.1590/S1516-89132006000400018

4. Lawal, A.K., Banjoko, A.M., Banjoko, A.M., Osikoyia, A.F., Olatope, S.O., Kayode, O.F., Etoamihe, M., Emoleila., I., Alebiosu, F.A., Majolagbe, Y.L, Shittu, K.A, Buhari, F. \& Dike, E.N. (2012). Production and optimal performance studies of glucose isomerase from agriculture raw material Global Adv. Res. J. Microbiol. 1(7), 108-119. http://garj./garj.org/index.htm

5. Angardi, V. \& Calik, P. (2013). Beet molasses based exponential feeding strategy for thermostable glucose isomerase production by recombinant Escherichia coli BL21 (DE3). J. Chem. Technol. Biotechnol. 88(5), 845-852. DOI: 10.1002/ jctb.3910.

6. Akdag, B. \& Calik, P. (2014). Recombinant protein production by sucrose-utilizing Escherichia coli W: untreated beet molasses-based feeding strategy development. J. Chem. Technol. Biotechnol. DOI: 10.1002/jctb.4411.

7. Ata, O., Boy, E., Gunes, H. \& Calik, P. (2014). Codon optimization of xylA gene for recombinant glucose isomerase production in Pichia pastoris and fed-batch feeding strategies to fine-tune bioreactor performance. Bioproc. Biosyst. Engineering. DOI: 10.1007/s00449-014-1333.

8. Dhungel, B., Subedi, M., Tiwari, K.B., Shrestha, U.T., Pokhrel, S. \& Agrawal, V.P. (2007). The thermostable glucose isomerase from psychrotolerant Streptomyces species. Int. J. Life Sci 1, 6-10. DOI: 10.3126/ijls.v1i0.2300.

9. Lee, C. \& Zeikus, J.G. (1991). Purification and characterization of thermostable glucose isomerase from Clostridium thermosulfurogenes and Thermoanaerobacter strain B6A. Biochem. J. 274, 565-571.

10. Bray, G.A., Nielsen, S.J. \& Popken, B.M. (2004). Consumption of high - fructose corn syrup in beverages may play a role in the epidemic of obesity. Am. J.Clin. Nutr. 79, 537-543. PMID 15051594.

11. Gromada, A., Fiedurek, J. \& Szczodrak, J. (2008). Isoglucose production from raw strachy materials based on a two-stage enzymatic system. Pol. J. Microbiol. 57(2), 141-148.

12. Gaily, M.H., Sulieman, A.K. \& Abasaeed, A.E. (2013). Kinetics of a three - step isomerization of glucose to fructose using immobilized enzyme. International J. Chem. Engine. Applic. 4(1), 31-34. DOI:10.7763/IJCEA.2013.V4.255.

13. Holt, J.G., Krieg, N.R., Sneath, P.H.A., Staley J.T. \& Williams, S.T. (1994). Bergey's Manual of Determinative Bacteriology ( $9^{\text {th }}$ ed.) Baltimore: Williams and Wilkins.

14. Kulka, R.G. (1956). Colorimetric estimation of ketopentoses and ketohexoses. Biochem J. 63, 542-548. PMID 13355847.

15. Lowry, O.H., Rosebrough, N.J., Farr, A.L. \& Randall, R.J. (1951). Protein measurement with folin- phenol reagent. J. Biochem. 193, 265-275. PMID 14907713.

16. Deshmukh, S.S., Deshpande, M.V. \& Shankar, V. (1994). Medium optimization for the production of glucose isomerase from thermophilic Streptommsces thermonitrificans. World J. Microbiol. Biotechnol. 10, 264-267. Doi: 10.1007/BF00414859.

17. Chou, C.C., Ladisch, M.R. \& Tsao, G.T. (1976). Studies on glucose isomerase from Streptomyces species. Appl. Environ. Microbiol. 32(4), 489-493. PMID 984827.

18. Chen, W.P., Anderson A.W. \& Han Y.W. (1979). Purification of glucose isomerase by Streptomyces flarogriseus. Appl. Environ. Microbiol. 37, 324-331. PMID 16345347.
19. Wong, H.C., Ting, Y., Lin, H.C., Reichert, F. \& Myambo, K. (1991). Genetic organization and regulation of the xylose degradation genes in Streptomyces rubiginosus. J. Bacteriol. 173, 6849-6858. PMID 1657868.

20. Kwakman, J.H.J.M. \& Postma, P.W. (1994). Glucose kinase has a regulatory role in catabolite repression in Streptomyces coelicor. J. Bacteriol. 176, 2694-2698. PMID 8169219.

21. Yassien, M.A.M. \& Jiman-Fatani, A.A.M. (2012). Optimization of glucose isomerase production by Streptomyces albaduncus. Afr. J. Microbiol. Res. 6, 2976-2984. DOI:10.5897/ AJMR12.016.

22. Whitlow, M., Howard, A.J., Finzel, B.C., Poulos, T.L., Winborne, E. \& Gilliland, G.L. (1991). A metal-mediated hydride shift mechanism for xylose isomerase based on the 1.6A Streptomyces rubiginosus structures with xylitol and D-xylose. Proteins 9, 153-173. DOI: 10.1002/prot.340090302.

23. Kasumi T., Hayashi, K. \& Tsumura, N. (1980). Purification and enzymatic properties of glucose isomerase from Streptomyces griseofuscus S-41. Agric. Biol. Chem. 45, 1087-1095. http:// dx.doi.org/10.1271/bbb1961.45.1087

24. Ryu, D.Y., Chung, S.H. \& Katoh, K. (1977). Performance of the continuous glucose isomerase reactor systems for the production of fructose syrup. Biotechnol. Bioeng. 19, 159-184. DOI: $10.1002 /$ bit.260190202.

25. Kitada, M., Dobshi, Y. \& Horikoshi, K. (1989). Enzymatic properties of purified D-xylose isomerase from a thermophilic alkalophile Bacillus TX-3. Agric Biol. Chem. 53(6), 1461-1468. DOI: $10.1271 /$ bbb1961.53.1461.

26. Danno, G.L. (1970). Studies on D-glucose-isomerizing enzyme from Bacillus coagulans strain HN-68. Agric. Biol. Chem. 34, 1805-1814. http://dx.doi.org/10.1271/bbb1961.34.1805 